\title{
Kasnodon Ukraine: History/Culture/Presumptions and Helping Developing Nations Move Forward
}

https://doi.org/10.21272/sec.5(3).92-97.2021.

R. Scott Colson, Esq., ORCID: https://orcid.org/0000-0002-7978-3882

Former Assistant to Birmingham Mayors (1983 - 2018), Honorary Consul for Ukraine to Alabama; Director Continuum of Care at Jimmie Hale Mission, USA

\begin{abstract}
This article chronicles some of my work in Ukraine in the late 90's until 2006 especially in the Donbas Region of Ukraine. This was a program funded by USAID through the US-Ukraine Foundation to promote democratic development in cities in Ukraine by establishing partnerships between American cities and Ukrainian cities. The partnership between Birmingham and Krasnodon became a model for the entire program and regular communication continued until the war in Donbas ended communications for most people. The program included topics including citizen involvement, water/sewer, transparency, economic development, education, transportation and public health.

I served under five different Mayoral administrations for 35 years in Birmingham and worked on a wide range of issues in that time including public safety, youth programs, arts and museums, international programs and economic development. This experience allowed me to access resources in Birmingham on a broad range of issues and create relationships between professionals in both communities. It also was the source of my love and admiration for the Ukrainian people which continues to this day in my role as Honorary Consul for Ukraine to Alabama. Much has changed in Ukraine during the 25 years I have worked with them. This article chronicles a couple of stories that exemplify some of the hazards and opportunities I have been a part of and hopefully can add to the wisdom and understanding of our two nations.

The younger generation of Ukrainians born to independence are showing more openness to change and attempting good new things. Helping them channel their idealism and energy in the face of threats and inertia is an honor and a real opportunity to fight for freedom.
\end{abstract}

Keywords: Ukraine, economic development.

JEL Classifications: F10, F30, 010.

Cite as: Colson, R.S. (2021). Kasnodon Ukraine: History/Culture/Presumptions and helping developing nations move forward. SocioEconomic Challenges, 5(3), 92-97. https://doi.org/10.21272/sec.5(3).92-97.2021.

Received: 23.04 .2021

Accepted: 10.09 .2021

Published: 13.09 .2021

Copyright: (C 2021 by the authors. Licensee Sumy State University, Ukraine. This article is an open access article distributed under the terms and conditions of the Creative Commons Attribution (CC BY) license (https://creativecommons.org/licenses/by/4.0/).

\section{Introduction}

I went to work with the Birmingham Mayor's Office in 1983 one week after completing the Bar exam. During my 35 years I served as coordinator of youth programs, liaison/coordinator for public safety/emergency management, coordinator of special events, liaison with museums, arts, and culture and director of Sister city programs as well as international economic development. I founded an EB5 program for the city and our Sister City programs four times was recognized as the best by Sister Cities International. I was honored to have a resolution on Tribute passed the US Senate in 2008 recognizing my work in Ukraine and in 2008 was named the Honorary Consul to Alabama for Ukraine, a title I hold. During my career I have volunteered, served on boards 
and been pro bono counsel to local and national programs for youth, foreign interests, mental health, substance abuse, homelessness and Christian Ministry as an ordained Deacon in the Baptist Church. I have been since 2018 the Director of Continuum of Care for Jimmie Hale Mission a large multi campus Christian program for homelessness and substance abuse counseling. Patience is a virtue and needed. But this article serves as a cautionary to those working with developing nations that it can be a vice and a dead end.

\section{Background}

I began my Ukrainian work in 1997 as part of the USAID Community Partners Program administered by USUkraine Foundation. Birmingham was one of 12 cities chosen to work on a project of sharing best municipal practices, development of civic society, citizen participation/democratization and economic development.

Birmingham was paired with Krasnodon, Ukraine. Krasnodon had been a prosperous coal mining region prior to the dissolution of the USSR. When approaching Krasnodon from the Oblast Capitol of Lughansk as you crest the hill above the Donetsk River valley where Krasnodon is, the view is like seeing the pyramids. Immense tailings pile from the mines dots the landscape and on a foggy morning you could swear they are pyramids. Like pyramids these piles had more to do with death than the future.

Ukraine in 1998 was in a technical term “a mess'. Imagine if your nation's history, currency, inspiring stories, friends, borders, language and beliefs suddenly disappeared or changed almost overnight. For Lughansk this was particularly jarring since it is in the Russified Eastern Ukraine. Russian is the predominate language and most media was from Russia. Now they were good Ukrainians not Soviets and not even Russian. An anecdote of the level of civil collapse in Krasnodon. Lughansk and Donetsk man hole openings in the street were marked with tree branches... why? Because all of the man hole covers had been stolen for scrap. In 1998 Ukrainian NGOs estimated that the $4^{\text {th }}$ largest source of hard currency coming into the country was from women who had left for sex work in Europe, Asia and Middle East and the USA.

\section{Coal in Krasnodon}

My best estimation of Krasnodon was "Imagine Appalachia in 1933 without the hope of the New Deal". Resources seldom filtered to the local economy. Krasnodon's mines were deep mines and very dangerous with approximately 200 deaths during the 7 years I was a regular visitor as part of this program, and countless cases of black lung and injury. The coal did not meet EU standards for export so most of the coal was for domestic and Easter European use.

On my first visit we met with miners. These miners had not been paid in over four months. The mines formerly state owned and now operated by private/oligarch interests in Kyiv. Like all of the ex Soviet states in 1992 GOP consultants flooded the place with ideas of trickle-down economics and immediate privatization, resulting in state assets being controlled by whoever had any money which meant, former black marketeers/gangsters, government appartchiks and in several instances former Spetzntaz officers. Miners were producing coal every but but were simply not being paid. In the meeting I had a miner ask me "How long would an American worker work without pay?" My answer was if they don't pay you have legal recourse and you just don't show up. They were gob smacked at these concepts of regulation and independence and holding businesses accountable in any way.

\section{Some Political Consideratons}

The parliament/Rada member for Krasnodon had not been seen since he was elected. With elections coming up I helped them create candidate forums and even taught them the trick of having a picture of the representative in an empty chair since he did not show up. In my first year working with Krasnodon the City Hall had a large bust of Lenin. After the election when a worker in the coal mine was elected to the Rada and a new mayor replaced the old communist mayor responsiveness to the people increased. Upon returning to city hall on my next visit the bust of Lenin was gone. I asked the Mayor about this and he said "It is in museum where it belongs! By the way where is confederate flag on Alabama capitol." Sadly, I had to answer that it was still there. Progress and also understanding that while we were there to help we were not the Gospel on all things! 
The event that changed the election was not the public forums so much as another event. A young miner was part of our meetings and was most interested. Yevgeny was someone desperate for change. Like many miners he had bags of coal he brought home from the mine that he sold on the road side to make money for his wife and children. A meager existence at best without electricity or running water (the towns water system and sewer system were failing), and no pay for 4 months for doing one of the most hazardous jobs in Ukraine over a kilometer deep in the Earth. After one of my trips the miners marched on the provincial capital of Lughansk demanding payment. While standing on the steps of the capital building making their plea, Yevgeny walked up the steps with a gas can. Stood at the top of the steps poured the gas over himself and set himself on fire and died at the scene. His hope was that this would spur the companies to pay the miners back wages and regularly pay them and was despondent that he could not provide for his family. The next week all the miners got paid. The moral of this story? There is no moral to it. It is desperation, despair and arrogance of the elites. This and other events made me unpopular at the embassy when we reported because I was convinced that the mistreatment of the east and denigration of Russian language and exploitation for the benefit of Kyiv and others would cause a civil war... and the future bore this out.

The miners in Krasnodon reminded me of miners in Appalachia and in north central Alabama. Proud to do a dangerous job that was part of a family tradition and often too patient in demanding fair treatment and mistrustful of the distant moneyed interests who decide their fate. And when they have met their limit capable of very direct action., when they have been ignored, exploited and looked down on for too long.

The patience of the poor be it in in the USA, Ukraine, Africa, Asia is an amazing feature. Patience is a virtue. But from my work in these areas it can also be a vice. An excuse to suffer for suffering sake. Miners who work for nothing and die with no expectation of assistance to their family is not virtuous for anyone involved. An example in Krasnodon. The huge tailings piles around town made of crushed rock. Not only were the man hole covers tree branches but the roads were in horrendous shape. Hot summers, cold wet winters do a number on roads. Some of the pot holes in the region had achieved land mark status in that directions would be, "You turn after the huge pot hole in the middle of the road that makes it one lane". We suggested early on to the Mayor at that time a Communist, that they take the crushed rock and fill pot holes as a temporary fix. He demurred on the theory that the tailing belonged to the mining companies. Our response, "The companies that haven't paid anyone or their taxes in months? If they show up asking about their rock piles ask them about their bill!" The concept we were advocated was, it is sometimes better to ask for forgiveness rather than permission in exigent circumstances. When they had elected a new Mayor, he was proud to show us the potholes filled with stone that help drivers navigate the streets and that he would ask for forgiveness and back payment if the companies came looking for the rocks.

\section{V. Emphasizing Patience and other examples of industry in Krasnodon}

Patience as pathology in the developing world is an issue not studied deeply but for those who have done it, is a real thing. The patience and sense of fatalism and the need to simply get through the day causes the acceptance of more misery than is necessary for these people and lack of planning, let alone dreaming. That is something we see in the USA, particularly my region of the south. The example of failure to use PPE during COVID and often failure to take precautions in tornado seasons is attributed to a religious faith they cite "That it is Lord's will/or the Lord will provide." A couple of Krasnodon examples.

The Krasnodon Maternity hospital served 150,000 people. Touring it showed conditions beyond any I have ever seen anywhere. Operating rooms had broken windows covered by newspaper. Power and water were intermittent. The Hospital had one baby that day and that week...in a city of 150,000. That baby was gasping for breath, blue and clearly not going to make it without an incubator...not a high-tech device just a basic incubator. None of theirs worked anymore and had not in months. The staff said there were weeks with no babies born. This was a city that had not enough faith in the future to have babies. They sent letters to Kyiv asking for more equipment but were denied because so few babies were being born, but abortion supplies were available. This was accepted with "Nychevo", a Russian phrase they used to mean...it can not be helped." To improve you must feel uncomfortable with where and what you are but the vise of patience and fatalism was actually fatal. 
We were to be shown a factory they believed could be used to create new jobs. It had been a furniture factory/wood shop during Soviet days and employed hundreds and had been closed for 4 years. The new owner, a politically connected woman, with no business experience had a request. She did not want money for equipment she just wanted the equipment to make it a competitive furniture/wood factory again. We tried to explain credit, capital (the equipment was capital investment she wanted even though she argued since it wasn't money it wasn't capital). Her argument did make some sense since under the Ukrainian tax law financial investments were taxed and almost $100 \%$ while equipment imports only had a large import fee. Ukraine has modernized their investments laws significantly but initially they made no economic sense within capitalist or communist thought.

The ride to the factory was an adventure. When we turned off the main road to the factory it was smooth concrete slabs. Half way to the factory on this 1.5 -kilometer road the slabs disappeared and we essentially trail riding in vehicles ill suited to the purpose. When got to the factory we asked about the road. The Chief of police was one of the VIPs with us and he responded, "Road stolen." We had to get translation and clarification for this. Apparently being close to the Russian border they had a problem of Russians coming with trucks in the night and stealing road make of concrete slabs and taking them back to Russia. A stolen road was anew concept for all of us.

When we entered the factory, it looked like a scene from a pos- Apocalyptic movie. Thich dust covered old wood work lathes, saws and other unrecognizable stuff. The ceiling and walls were covered with red banners exhorting the workers to meet the 5-year plan and to work for the advancement of the Rodina. The building was a mess with holes in the roof and weak walls. A building ready to be bulldozed and more economically to be bull dozed and with no real historical significance. We tried to explain how this was a very unlikely investment site for foreigners for many reasons. As I wandered the floor I found a boiler room where the equipment was spotless and looked ready to go. How in the world is this possible!? Down the hall was an office with a bed, night stand chest, small stove and it was neatly kept. Out side the window was a beautiful kitchen garden and chickens and a few goats. I called the group over. A lady came out to say hello. She had been the supervisor of the boiler when the factory ran. When it closed she had nowhere else to go so she moved in and keeps the boiler clean and lives in the factory and had been there for four years. Patiently waiting for someone to reopen the factory. Granted opportunity is limited there but patience as a vice becomes clear when one makes a home in ruins in the hope that things will come back.

\section{My Experience in China with Economic Development}

The other illustrative story begins in China in 1998. I was there as part of business cultural exchange with our Sister Cities and others. We made a stop in Hong Kong to meet with Alabama's official representative in China George Lieu. George worked for Alabama and a couple of other states to help them develop business relationships with China. Over dinner George told me he was also affiliated with Preston, Gates law firm the primary law firm for Microsoft. At that time Microsoft was developing its Iridium satellite communication system. The initial primary launch vehicle was to be the Space Shuttle but cut backs in shuttle launches due to safety reviews and such had made the roll out of launches way behind schedule. I told George I had come across a company in Lughansk that made guidance systems for space rockets. Microsoft had turned to China for launch services for Iridium but the Chinese rockets were knock offs of Russian missiles and they were having poor success with flights due to guidance issues. This factory in Ukraine made systems for that very rocket. It was being kept open even though Russian cutbacks in defense in space meant they weren't selling the systems they were making, they were simply being kept afloat by the government to maintain the option of making these systems. I told George about this and that they had a readymade inventory for that rocket. We had visions of a multimillion dollar shot in the arm for that factory and a chance to get Iridium functional. I excitedly got in touch with the Ukrainian embassy and the factory thinking they would jump at the chance. They were not interested. The taxes were over $100 \%$ on selling the systems and they did not want to sell to foreigners since it was for their rocket industry which was producing nothing. With great disappointment George and I gave up. Microsoft helped China develop guidance systems (thereby assisting their space and weapons program) so as to get Iridium in orbit. A failure to think big because of patience with a moribund status quo. 


\section{Perspective}

In short Ukraine has been a labor of love for me. We have hosted dozens of Ukrainians in our home and I cherish my connections there. The challenges in Ukraine and other developing nations is as much a psychological approach or mind set as economics and politics. Birmingham was a city mired in racial division fostered by ruling classes and an unhealthy reliance on one industry, steel and iron. When that industry faltered and failed in the early 80 's we had a choice, death or change. Fortunately, we had the development of UAB, which has become a world class medical and research system. The growth of the University and industries created by the new creative class has caused a transformation. While we still make a lot of steel and iron we are primarily a city based on this world class university which is the largest employer in the state. We were blessed in congressional and local leadership that embraced change as embodied by the first President of UAB who said. "We would do Birmingham a great disservice if we dreamed too-little dreams."

The change in Birmingham on race, economics, politics and culture was because of decisions based on asking "why not?" and embracing change and audacity. I have worked in several places to share this and it is hard. People love familiarity and a sense of permeance in an impermanent world even when that permanence is miserable. Patience is a virtue only if you are working toward a goal. Patience as fatalism is death.

\section{Summary and Conclusion}

While anecdotal these experiences are illustrative of the issues in dealing with a post-Soviet nation. The examples of patience/fatalism shown can be seen in poor rural and urban areas of this nation. The lack of being able to think that hope is an option is a symptom of systems that minimize individual rights, responsibilities and possibilities. Be it a collectivist mentality Ukraine or a Libertarian total disregard of the concept of a common good, the inevitable result for the non-connected average person is powerlessness. Powerlessness manifests as here in fatalistic life view that simply awaits salvation form somewhere or in revolution when that powerlessness becomes anger, as has had happened in Ukraine on several levels with some good and some questionable results. In conclusion without hope and a belief that change is possible there can be little hope for freedom and change.

Funding: self-funded.

Author contribution: conceptualization, R. Scott Colson; data curation, R. Scott Colson; R. Scott Colson formal analysis, R. Scott Colson; funding acquisition, R. Scott Colson; investigation, R. Scott Colson; methodology, R. Scott Colson; project administration, R. Scott Colson; resources, R. Scott Colson; software, R. Scott Colson; supervision, R. Scott Colson; validation, R. Scott Colson; visualization, R. Scott Colson; writing - original draft, R. Scott Colson; writing - review \& editing, R. Scott Colson.

\section{Acknowledgement}

Thanks for helpful comments from Paul Gentle, Ph.D.

\section{References}

1. Anders, Aslund (2009). How Ukraine Became Market Economy and Democracy, Washington, D.C.: Peterson Institute for International Economics. Available at: [Link].

2. Casanova, Jose', and Georgiy Kasianov Tyvanofiy,Mylovancy, Margarita M. Balmaceda, Oksanarshynova, Tymofii Brik, Diana Dutsyk, Marta Dyczok, Hennadii Korzhov, Serhiy Kudelia, Pavlo Kutuev, Olena Martynyuk, Oksana Mikheieva, Mykhailo Minakov, Andrian Prokip, Matthew Rojansky, Oxana Shevel, Ilona Sologoub, Maksym Yenin, Yuliya Yurchenko (2021). From "the Ukraine" to Ukraine: A Contemporary History, 1991-2021. Hanover, Germany: Ibidem Press. Available at: [Link].

3. D'Anieri, Paul (2019). Ukraine and Russia: From Civilized Divorce to Uncivil War Cambridge, UK: Cambridge University Press. Available at: [Link].

4. Grossman, Vasily Semyonovich (2009). Everything Flows, New York: NYRB Classics. Available at: [Link].

5. Krawchenko, Tamara, Iryna Tsilyk and Arthen Checkh (2015). Awesome Ukraine. Interesting Things You Need to Know. Kyiv, Ukraine: Osnovy Publishing. Available at: [Link]. 
6. Magocsi, Paul Robert (2007). Ukraine: An Illustrated History. Toronto, Canada: Universityof Toronto Press. Available at: [Link].

7. Orest Subtelov (2009). Ukraine: A History, $4^{\text {th }}$ edition. Toronto, Canada: University of Toronto Press, Scholarly Publishing Division. Available at: [Link].

8. Pieniazek, Pawel, Translators: Margaret Markoff and John Markoff (2017). Greetings from Novorosslya: Eyewitness to the War in Ukraine. Pittsburgh: University of Pittsburgh. Available at: [Link].

9. Pleshakov, Constative (2017). The Crimean Nexus: Putin's War and the Clash of Civilizations. New Haven, Connecticut, Yale University Press. Available at: [Link].

10. River, Charles (2009). Ukraine: The History and Legacy of Ukraine from the Middle Ages to Today. Ann Arbor, Michigan: Charles River Editors. Available at: [Link].

11. Shevchenko, Anna (2012). Ukraine: The Essential Guide to Customs and Culture. London, UK: Kuperard publishing. Available at: [Link].

12. Sloniowska, Zanna (2018). The House with the Stained Window, Hachette, UK: MacLehose Press. Available at: [Link].

13. Wilsom, Andrew (2014). Ukraine Crisis: What it Means for the West. New Haven, Connecticut, Yale university Press. Available at: [Link].

14. Yekelchvk, Serhii (2007). Ukraine: Birth of a Modern Nation. Oxford, UK: Oxford University Press. Available at: [Link].

15. Yermolenko, Volodymyr (editor) (2020) .Ukraine in Histories and Stories: Essays by Ukranian Intellectuals, Stuttgart: Ibeidem - Verlag. Available at: [Link].

16. Yekelchyk, Serhii (2020). Ukraine: What Everyone Needs to Know? Oxford University Press. Available at: [Link]. 